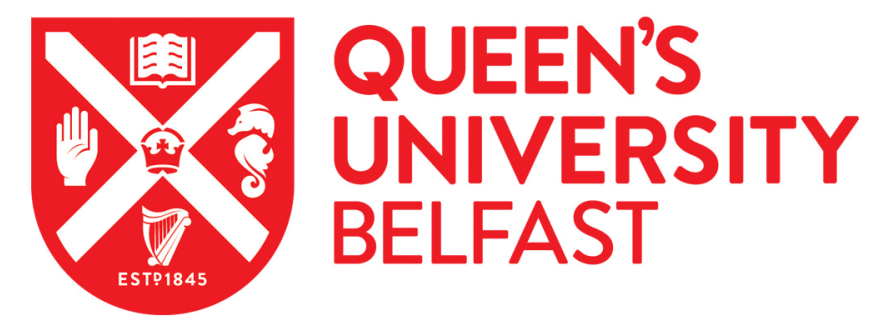

\title{
Historical phosphorus dynamics in Lake of the Woods (USA-Canada) - does legacy phosphorus still affect the southern basin?
}

Edlund, M. B., Schottler, S. P., Reavie, E. D., Engstrom, D. R., Baratono, N. G., Leavitt, P. R., Heathcote, A. J., Wilson, B., \& Paterson, A. M. (2017). Historical phosphorus dynamics in Lake of the Woods (USA-Canada) does legacy phosphorus still affect the southern basin? Lake and Reservoir Management, 33(4), 386-402. https://doi.org/10.1080/10402381.2017.1373172, https://doi.org/10.1080/10402381.2017.1373172

Published in:

Lake and Reservoir Management

Document Version:

Peer reviewed version

Queen's University Belfast - Research Portal:

Link to publication record in Queen's University Belfast Research Portal

Publisher rights

(C) 2017 Copyright by the North American Lake Management Society.

This work is made available online in accordance with the publisher's policies. Please refer to any applicable terms of use of the publisher. javascript:void(0);

\section{General rights}

Copyright for the publications made accessible via the Queen's University Belfast Research Portal is retained by the author(s) and / or other copyright owners and it is a condition of accessing these publications that users recognise and abide by the legal requirements associated with these rights.

Take down policy

The Research Portal is Queen's institutional repository that provides access to Queen's research output. Every effort has been made to ensure that content in the Research Portal does not infringe any person's rights, or applicable UK laws. If you discover content in the Research Portal that you believe breaches copyright or violates any law, please contact openaccess@qub.ac.uk. 


\section{Historical phosphorus dynamics in Lake of the Woods}

(USA-Canada) -

\section{Does legacy phosphorus still affect the southern basin?}

5 Mark B. Edlund* ${ }^{1}$, Shawn P. Schottler ${ }^{1}$, Euan D. Reavie ${ }^{2}$, Daniel R. Engstrom ${ }^{1}$, Nolan

6 Baratono $^{3}$, Peter R. Leavitt ${ }^{4}$, Adam J. Heathcote ${ }^{1}$, Bruce Wilson ${ }^{5}$, Andrew M. Paterson ${ }^{6}$

$7 \quad{ }^{1}$ St. Croix Watershed Research Station, Science Museum of Minnesota, $16910152^{\text {nd }}$ St. North, Marine on St. Croix, MN 55047 USA

${ }^{2}$ Natural Resources Research Institute, University of Minnesota Duluth, 5013 Miller Trunk Hwy, Duluth, MN 55731 USA

${ }^{3}$ Watershed Ecology, 909 Riverside Dr, International Falls, MN 56649 USA

${ }^{4}$ Department of Biology, University of Regina, 3737 Wascana Parkway, Regina, SK, S4S 0A2

${ }^{5}$ RESPEC, 1935 County Road B2 W \# 320, St Paul, MN 55113 USA Change, 1026 Bellwood Acres Road, P.O. Box 39, Dorset, ON, P0A 1E0 Canada

$18 *$ Corresponding author, medlund@smm.org

19 Abbreviated Title: Historical Phosphorus Dynamics and Paleolimnology 


\section{Abstract}

22 A historical phosphorus (P) budget was constructed for southern Lake of the Woods. Sediment

23 cores from seven bays were radioisotopically dated and analyzed for loss-on-ignition, $\mathrm{P}, \mathrm{Si}$,

24 diatoms, and pigments. Geochemical records for cores were combined using focusing factors for

25 whole-basin estimates of sediment, total $\mathrm{P}$, and $\mathrm{P}$ fraction accumulation. Although historical

26 monitoring shows that external P loads decreased since the 1950s, sediment $\mathrm{P}$ continues to

27 increase since the mid- $20^{\text {th }}$ century. Much sediment $\mathrm{P}$ is labile and may be mobile within the

28 sediments and/or available for internal loading and resuspension. Two mass-balance models

29 were used to explore historical P loading scenarios and in-lake dynamics, a static one-box model

30 and a dynamic multi-box model. The one-box model predicts presettlement external loads were

31 slightly less than modern loads. The dynamic model showed that water column $\mathrm{P}$ was higher in

32 the 1950s-1970s than today, that the lake is sensitive to external loads because P losses from

33 burial and outflow are high, and that the lake is moving to a new steady state with respect to

34 water column P and size of the active sediment P pool. The active sediment pool built up in the

35 mid- $20^{\text {th }}$ century has been depleted through outflow and burial, such that its legacy effects are

36 now minimal. Comparison of historical nutrient dynamics and sediment records of algal

37 production showed a counterintuitive increase in production after external P loads decreased,

38 suggesting other drivers may now regulate modern limnoecology, including seasonality of $\mathrm{P}$

39 loading, shifting nutrient limitation, and climate warming.

40 Key Words: cyanobacteria, internal phosphorus loading, large lakes, paleolimnology, shallow

41 lakes 
43 Control and mitigation of excess nutrients, particularly phosphorus (P), continues to dominate

44 lake management efforts (Schindler 2012, Schindler et al. 2016). In the USA, over $40 \%$ of lakes

45 are impaired for phosphorus (USEPA 2016) and nutrient triggered cyanobacterial blooms are a

46 global problem (Paerl et al. 2011). Measurements and models for determining basin P loading

47 and sediment $\mathrm{P}$ burial, resuspension, and aerobic and diffusive loading are critical for addressing

48 nutrient management and recovery from eutrophication. Many methods and models have been

49 developed to estimate whole basin and sediment fluxes (James and Barko 1993, Brenner et al.

50 2006), P retention capacity of sediments (Kopáček et al. 2007, Wilson et al. 2010), and long-term

51 and short-term P dynamics (Xie and Xie 2002, Norton et al. 2011, Wang et al. 2003).

52 Importantly, these modeling exercises have been directed at nutrient-impaired waters throughout

53 the world, although lake-specific models are often required (Havens et al. 2001). Resulting

54 management efforts primarily target point and non-point P loadings; however, impaired lake

55 conditions are often exacerbated by internal P loading through chemical release (especially under

56 anoxic hypolimnetic conditions; Boström et al. 1982) and sediment resuspension. Internal

57 loading may continue to determine lake condition even after significant reduction in external

58 loads (Jeppesen et al. 2005, McCrackin et al. 2016).

59 Lake of the Woods (LoW) is a large, multibasin lake located along the borders of

60 Minnesota (USA), Ontario and Manitoba (Canada). The lake extends about $100 \mathrm{~km}$ on both

61 longitudinal and latitudinal axes, with the largest surface area in Big Traverse Bay, which

62 connects to several secondary basins including Buffalo and Muskeg bays to the south and west,

63 and Sabaskong Bay to the east. Water flows northward through Little Traverse Bay before

64 passing through Big Narrows to join outflow from several deeper Canadian basins, bays, and

65 outflows before discharging into the Winnipeg River at Kenora, Ontario. Overall, mean 
66 residence time is $1.71 \mathrm{yr}$ (2000-2010; Zhang et al. 2013). Its major inflow is the Rainy River,

67 which enters the southeast end of the lake near Baudette, Minnesota (Anderson et al. 2017).

With the publication of the Lake of the Woods State of the Basin Report (DeSellas et al.

69 2009; updated $2^{\text {nd }}$ Ed., Clark et al. 2014) and the Minnesota Pollution Control Agency's

70 placement of the lake in 2008 on the state's list of waters impaired for nutrients and

71 eutrophication indicators, the future of the lake became a high profile concern for Canada,

72 Minnesota, First Nations and tribal governments, as well as the lake's stakeholders. The Basin

73 Report highlighted nutrients and their biological impacts - primarily cyanobacterial blooms and

74 a perceived increase in the frequency and extent of these nuisance blooms - as a primary

75 resource concern for the lake.

76 Lake of the Woods has elevated concentrations of $\mathrm{P}$ in comparison to other lakes on the

77 Precambrian Shield, a strong N-S gradient of water quality (Pla et al. 2005), and extensive

78 cyanobacterial blooms (Binding et al. 2011). Although these characteristics have some historical

79 precedence (Anderson et al. 2017), recent trends in lake ecology have been at odds with known

80 effects of resource management. For example, monitored P loads from the Rainy River, the

81 primary external source of $\mathrm{P}$, have decreased over the last 40 years, mainly due to improved

82 management of point sources (Hargan et al. 2011). Following nutrient abatement programs,

83 Rainy River water quality between the 1990s and 2000s shows little change in nutrient content

84 (Hargan et al. 2011), which is further reflected in minimal change in in-lake nutrient

85 concentrations based on the limited monitoring data available. Furthermore, paleoecological

86 evidence from Canadian waters of northern LoW demonstrates little change in diatom-inferred $\mathrm{P}$

87 values (Rühland et al. 2008, 2010, Hyatt et al. 2011, Paterson et al. 2017), whereas fossil

88 reconstructions from a small bay in the south basin shows increasingly eutrophic conditions 
89 (Reavie and Baratono 2007). Cyanobacterial blooms are perceived to be more frequent and of

90 greater spatial coverage than in previous decades, particularly in the southern basin, although

91 evidence from monitoring, including satellite imagery, is equivocal (Chen et al. 2007, 2009,

92 Binding et al. 2011).

93 Weak relationships between documented declines in nutrient influx and observed water

94 quality may reflect either a strong legacy effect of sedimentary nutrients or establishment of

95 alternative mechanisms regulating limnological conditions, such as climate induced reduction in

96 water-column mixing and reduced thermal structure (Paerl and Huisman 2008). In response to

97 these challenges, management initiatives include an increase in the spatial and temporal

98 resolution of monitoring, evaluation of satellite imagery, tests for cyanobacterial toxins, and

99 development of a comprehensive P mass budget for the lake (Clark et al. 2014). To complement

100 these initiatives, managers also need a detailed historical evaluation of nutrient dynamics of LoW

101 to quantify the magnitude and timing of disconnect between changes in nutrient loading and lake

102 response. In particular, sediments record changes in sedimentary $\mathrm{P}$ accumulation, as well as the

103 chemical nature of $\mathrm{P}$ fractions, and often reveal how these factors vary in response to external

104 loading, land use, climate and other factors (Anderson et al. 1993, Ginn et al. 2012).

105 Historical and paleoecological techniques for estimating past $\mathrm{P}$ influx and temporal

106 dynamics have proven useful in developing cooperative management strategies in other nutrient-

107 enriched transboundary waters such as Lake Pepin and Lake St. Croix, smaller basins within the

108 Upper Mississippi River (Edlund et al. 2009, Engstrom et al. 2009; Triplett et al. 2009). In those

109 lakes, historical phosphorus mass balances, which estimated inputs based on the sum of whole

110 basin burial estimates and diatom-based estimates of $\mathrm{P}$ loss in outflows, indicated that P loading

111 to each lake had increased rapidly after World War II in response to growing populations and 
112 increased point and nonpoint source loadings. Concomitantly, diatoms showed dramatic

113 ecological changes in the last 200 years, while diatom-inferred P concentrations increased after

114 Euro-American settlement and the mid $20^{\text {th }}$ century. In contrast, recent analysis of sedimentary

$115 \mathrm{P}$, diatoms and fossil pigments from phytoplankton in larger prairie basins (e.g., Lake Winnipeg,

116 L. Manitoba) suggest that lake production can be disconnected from estimates of $\mathrm{P}$ influx,

117 particularly in poorly stratified waters (Bunting et al. 2016). Given the size and depth of

118 southern LoW, it may be difficult to predict how production may have responded to nutrient

119 management.

120 This project uses a combination of sedimentary $\mathrm{P}$ analysis, multi-proxy fossil analysis of

121 phytoplankton (diatoms, pigments) and dynamic nutrient modeling to reconstruct historical

122 changes in nutrient fluxes and conditions in southern LoW. In conjuction with a coupled

123 paleolimnology effort (Reavie et al. 2017), we address these research questions:

124 1. Does the sediment P record accurately reflect the lake's $P$ loading history?

125 2. How have P loadings to LoW changed over the last 150 years?

126 3. Can in-lake P dynamics be modeled to understand historical, legacy, and future nutrient

127 dynamics?

128 4. Do trends in core biogeochemistry and biological indicators reflect historical nutrient

129 dynamics?

\section{Materials and Methods}

\section{Coring}

133 Sediment cores were recovered from deep, flat depositional zones in seven basins in LoW (Table

134 1, see also Reavie et al. 2017). Most cores were recovered with a piston corer consisting of a 6.5 
$135 \mathrm{~cm}$ diameter polycarbonate tube outfitted with a piston and operated with rigid drive rods from

136 the ice surface (Wright 1991). A follow-up core was recovered the following summer from

137 Buffalo Bay using a gravity corer (Renberg and Hansson 2008). Piston cores ranged in length

138 from 90 to $98 \mathrm{~cm}$, and the gravity core from Buffalo Bay was $9.5 \mathrm{~cm}$ long. All cores were

139 stabilized with Zorbitrol (Tomkins et al. 2008) or sectioned immediately in the field in $0.5-\mathrm{cm}$

140 increments to $10 \mathrm{~cm}$ depth using a vertical extrusion system. For piston cores, unextruded core

141 material was sealed in its polycarbonate tube and transported horizontally back to the laboratory

142 for further sectioning in 1-cm increments from $10 \mathrm{~cm}$ to $35 \mathrm{~cm}$ (to $60 \mathrm{~cm}$ for Sabaskong and Big

143 Narrows cores).

\section{Isotopic Dating, Biogeochemistry, and Whole-Basin Deposition}

145 Sediment cores were analyzed for ${ }^{210} \mathrm{~Pb}$ activity to determine age and sediment accumulation 146 rates over the past 150 to 200 years. Lead-210 activity was measured from its daughter product,

$147{ }^{210} \mathrm{Po}$, which is considered to be in secular equilibrium with the parent isotope. Aliquots of

148 freeze-dried sediment were spiked with a known quantity of ${ }^{209} \mathrm{Po}$ as an internal yield tracer and

149 the isotopes distilled at $550^{\circ} \mathrm{C}$ after treatment with concentrated $\mathrm{HCl}$. Polonium isotopes were

150 then directly plated onto silver planchets from a $0.5 \mathrm{~N} \mathrm{HCl}$ solution. Activity was measured for

$151-3 \times 10^{5} \mathrm{~s}$ using an Ortec alpha spectrometry system. Supported ${ }^{210} \mathrm{~Pb}$ was estimated by mean

152 activity in the lowest core samples and subtracted from upcore activity to calculate unsupported

$153{ }^{210} \mathrm{~Pb}$. Core dates and sedimentation rates were calculated using the constant rate of supply model

154 (Appleby and Oldfield 1978, Appleby 2001). Dating and sedimentation errors represented first-

155 order propagation of counting uncertainty (Binford 1990). For cores with problematic activity

156 profiles, gamma spectrometry was used to measure supported ${ }^{210} \mathrm{~Pb}\left(\right.$ as $\left.{ }^{214} \mathrm{~Pb}\right)$ and identify the

1571963 dating marker associated with the peak in ${ }^{137} \mathrm{Cs}$ activity. The short-lived isotope ${ }^{7} \mathrm{Be}$ (half 
158 life $53.2 \mathrm{~d}$ ) was also measured in the uppermost intervals of select cores using gamma

159 spectrometry to determine the extent of sediment mixing from bioturbation and resuspension.

160 To understand whole basin depositional rates for various constituents including dry bulk

161 sediment and P fractions, a "focusing factor" was calculated for each core using the method of

162 Engstrom and Rose (2013) and Hobbs et al. (2013) to normalize for downcore fluxes among

163 basins. Focus factors estimate the degree to which each core site integrates sediment within a

164 basin by comparing atmospheric flux to unsupported ${ }^{210} \mathrm{~Pb}$ inventory at the core site.

165 Atmospheric flux of ${ }^{210} \mathrm{~Pb}$ in northern Minnesota is estimated at $0.45 \mathrm{pCi} / \mathrm{cm}^{2} \mathrm{yr}$ (Lamborg et al.

166 2013). Sedimentation rates for individual basins were corrected for sediment focusing, the data

167 for all cores pooled, and averaged among time intervals represented by approximately equal

168 numbers of observations (5-year window back to 1990, decadal intervals to 1940, 20-year

169 intervals to 1900 , and pre-1900 samples grouped) to estimate whole lake sedimentation rates.

170 Bulk-density (dry mass per volume of fresh sediment), organic, carbonate, and mineral

171 content, and biogenic silica (BSi) concentrations and accumulation rates were determined for all

172 cores. Details of these geochemical procedures are provided by Reavie et al. (2017). Sediment P

173 was analyzed following the sequential extraction procedures in Engstrom (2005) and Engstrom

174 and Wright (1984). Extracts were measured colorimetrically on a Lachat QuikChem 8000 flow

175 injection autoanalyzer. Sediment $\mathrm{P}$ concentrations were also converted to flux using bulk

176 sedimentation rates in each core. In addition to total $\mathrm{P}$, sediment fractions include the refractory

177 forms HCl-P and Organic-P and labile forms $\mathrm{NaOH}-\mathrm{P}$ and exchangeable $\mathrm{P}$ (Ex-P).

178 Biological constituents measured in all cores included diatom and chrysophyte

179 microfossils and fossil algal pigments; analytical procedures and results are presented by Reavie 180 et al. (2017). To estimate historical water column total P, or diatom-inferred total P (DI-TP), a 
181 diatom calibration set constructed by Hyatt et al. (2011) was applied to relative abundance data

182 of downcore diatom assemblages using weighted averaging regression with inverse deshrinking.

183 Calibration model performance and reconstruction statistics are presented in Reavie et al. (2017).

184 Modeling Historical Phosphorus Dynamics

185 Two modeling approaches were developed and applied to downcore data to understand historical

186 nutrient dynamics, historical P loads, and current nutrient trajectories. Model 1 is a simple one

187 box whole-lake mass balance, whereas Model 2 is a three-box dynamic model run from 1850 to

188 present. Each model is presented below with its conceptual basis, assumptions, input data, and a

189 discussion of its results, trends, potential shortcomings, and key findings. Model 2 was

190 assembled and run using the software Stella 9.0 (isee systems inc., Lebanon, NH,

191 Www.iseesystems.com).

192 Supporting data for modeling of historical P budgets came from several sources. For

193 Model 1, historical water column P was estimated using diatom-inferred total P (DI-TP)

194 reconstructions from all cores (Table 2; Reavie et al. 2017). Lake area was calculated from

195 polygons digitized from aerial photography using the software QGIS (QGIS Development Team

196 2015) and lake volume by basin was taken from Zhang et al. (2013). Outflow rates to the

197 Winnipeg River at Kenora were available from 1927-2008 and provided by the Lake of the

198 Woods Water Control Board (lwcb.ca). Outflow at the Big Narrows was scaled based on

199 supplemental data provided in Zhang et al. (2013) by comparing daily step outflow from 2000-

2002010 at the Big Narrows to Kenora. Phosphorus loadings from the Rainy River were assembled

201 from available records from 1954-present, including compilations by Beak Consultants Ltd

202 (1990) and Hargan et al. (2011), and recent monitoring coordinated by the Minnesota Pollution

203 Control Agency (Table 3). Data were summarized using decadal average flows and arithmetic 
means of measured TP. Other sources of P loads to the lake including atmospheric deposition, minor tributaries, and shoreline erosion were taken from Hargan et al. (2011) and HEI (2013).

207 Results

\section{Sediment core records}

209 Most cores from LoW showed monotonic exponential declines in ${ }^{210} \mathrm{~Pb}$ inventories to depths 210 with background (supported) activities (Fig. 1). Cores generally reached supported levels of

$211{ }^{210} \mathrm{~Pb}$ around 25 to $35 \mathrm{~cm}$ depth, except for Buffalo Bay, where supported levels were reached at

$2127-8 \mathrm{~cm}$. Supported ${ }^{210} \mathrm{~Pb}$ activities ranged from $0.85 \mathrm{pCi} / \mathrm{g}$ (Muskeg Bay) to $1.28 \mathrm{pCi} / \mathrm{g}$ (Big

213 Narrows). Sediments dated to 1900 correspond to the approximate period of European settlement

214 and damming of the lake at Kenora (Clark et al. 2014) and were found between $17 \mathrm{~cm}$ (Little

215 Traverse) and $34 \mathrm{~cm}$ (Sabaskong Bay) downcore, except for Buffalo Bay $(\sim 7.5 \mathrm{~cm})$. Buffalo Bay

216 began to accumulate lacustrine sediments at ca. 1900, likely in response to damming at Kenora,

217 which raised LoW water levels by $\sim 1 \mathrm{~m}$ (Clark et al. 2014). Sediment focusing factors varied

218 among the core sites from 0.41 at Buffalo Bay to 1.87 in Sabaskong Bay (Table 1). The short-

219 lived isotope ${ }^{7} \mathrm{Be}$ (half-life $53.2 \mathrm{~d}$ ) was measured in select cores and detected to depth of 1 to 4

$220 \mathrm{~cm}$; if ${ }^{7} \mathrm{Be}$ can be detected in sediments dated by ${ }^{210} \mathrm{~Pb}$ at $6-10$ years old, sediment mixing must

221 be occurring in LoW at least to some degree (data not shown).

222 Most cores showed increasing sedimentation rates in more recent deposits with modern

223 rates typically two-fold greater than those before 1900 (Fig. 1). Some cores had slightly greater

224 increases in sedimentation rates including the Big Traverse Bay and Little Traverse Bay cores,

225 with recent sedimentation nearly three times pre-1900 rates. Little Traverse and Muskeg bays

226 had secondary increases in sedimentation rates since the 1970s and 1980s, respectively. Modern 
227 sedimentation rates varied from 0.6 (Big Traverse 4) to $1.2 \mathrm{~kg} / \mathrm{m}^{2} \mathrm{yr}$ (Sabaskong Bay), whereas

228 presettlement rates ranged from less than 0.1 (Big Traverse 3) to $0.6 \mathrm{~kg} / \mathrm{m}^{2} \mathrm{yr}$ in Muskeg Bay.

229 Following correction for sediment focusing in each basin and pooling of all cores based on

230 averaged time intervals, estimates of whole-lake sedimentation rates increased from a pre

231 settlement rate of $0.27 \mathrm{~kg} / \mathrm{m}^{2}$ yr to a peak in the $1970 \mathrm{~s}$ of $0.69 \mathrm{~kg} / \mathrm{m}^{2} \mathrm{yr}$. Whole-basin

232 sedimentation rates declined slightly in the 1980 s but have risen to approximately $0.7 \mathrm{~kg} / \mathrm{m}^{2} \mathrm{yr}$

233 since the 1980s (Fig. 2a).

234 Total $\mathrm{P}$ in LoW sediment ranged from 0.4 to over $1.0 \mathrm{mg} \mathrm{P} / \mathrm{g}$ dry mass (Fig. 3). The

235 organic-P and NaOH-P fractions were most abundant in Big Traverse 4, Little Traverse Bay,

236 Sabaskong Bay, and Big Narrows. In contrast, HCl-P was a predominant P fraction in Big

237 Traverse 3, Buffalo Bay, and deeper sediments of Little Traverse and Muskeg bays. In all cores

238 the accumulation rates of sediment $\mathrm{P}$ and fractions increased 2- to 3 -fold over the $20^{\text {th }}$ century,

239 with to highest levels at the core surface. Based on historical estimates of P loading from the

240 Rainy River, there have been significant declines in P loading since the mid-1970s to present day

241 that are 2- to 3-fold less than loading estimates derived from 1950s-1970s. However, there is no

242 clear indication of decreased accumulation of $\mathrm{P}$ in the sediments in response to decreased

243 external loads, possibly because upward mobility of $\mathrm{P}$ within the sediments obscures the trend of

244 P inputs to the sediments (James et al. 2015).

245 Whole lake $\mathrm{P}$ accumulation rates were estimated from the time-averaged sum of $\mathrm{P}$

246 accumulation estimates from all sites, each independently corrected for sediment focusing (Fig.

247 4a). The $\mathrm{P}$ fractions were also treated separately as refractory (HCl-P, Org-P) or labile

248 (potentially exchangeable) fractions (Ex-P, NaOH-P; Fig. 4a). Labile fractions are prevalent in 
249 all levels of LoW sediments with the amount increasing upcore, consistent with the expectation 250 that these $\mathrm{P}$ fractions are potentially mobile within the sediment profile.

251 Because burial of $\mathrm{P}$ is often the primary mechanism that removes $\mathrm{P}$ from a lake, we

252 developed a conceptual model that considers the historically or permanently buried $\mathrm{P}$ and the

253 active pool of $\mathrm{P}$ (Fig. 4b). We recognize that a significant proportion of the $\mathrm{P}$ in upper sediment

254 layers represents an active pool of $\mathrm{P}$ that can be exchanged with the overlying waters or within

255 the cores via mobility and bioturbation. In addition, the active pool is not restricted to the labile

256 fractions because of resuspension (James 2017) and because labile P fractions are present in deep

257 sediments (Fig. 4a). We also recognize from the ${ }^{7} \mathrm{Be}$ inventory that sediments may be rapidly

258 mixed in LoW down to $5 \mathrm{~cm}$. Because of these factors (mixing, resuspension, within-core

259 mobility) we do not know at the time of coring and at a given sediment depth what proportion of

$260 \mathrm{P}$ is actually buried. Therefore, for modelling purposes our conceptual basis recognizes that there

261 is a pool of P available for exchange ("Active"; Fig. 4b) and a pool of P that is truly buried and

262 no longer available for exchange with the lake ("Buried"; Fig. 4b). Model 2 explores the

263 behavior of these pools, particularly the net flux of $\mathrm{P}$ from the active pool via diffusion and

264 resuspension to estimate water column TP concentration, and uses the whole-basin inventory of

265 sediment P (active plus buried) in sediments deposited from 1860-2011 as a modelling target

266 (see Model 2 below).

267 Among the seven cores analyzed for diatoms, most show continuous upcore increases in

268 DI-TP (Fig. 3, see also Reavie et al. 2017). Analysis of all cores, except Buffalo Bay (no $19^{\text {th }}$

269 century sediments), suggested that background (pre-Euroamerican settlement) TP concentrations

270 in the water column to be approximately $10 \mu \mathrm{g} \mathrm{P} / \mathrm{L}$ throughout the southern LoW. Cores from

271 Muskeg, Big Narrows, and Big Traverse 4 showed increasing DI-TP upcore after 1900, whereas 
272 Big Traverse 3, Sabaskong, and Little Traverse had more marked increases in DI-TP after 1950.

273 Overall, Buffalo Bay had the highest DI-TP values than all other cores from LoW with recent

274 values exceeding $30 \mu \mathrm{g}$ P/L. Values of DI-TP from the most recent sediments of other cores

275 were typically between 20 and $30 \mu \mathrm{g}$ P/L with several cores exceeding $30 \mu \mathrm{g} \mathrm{P} / \mathrm{L}$ in the

276 uppermost sections (Big Narrows, Muskeg, Buffalo Bay).

277 The DI-TP reconstructions of six cores were combined (Buffalo Bay omitted in pre-1900

278 as it did not preserve a predamming record) by time increment to estimate whole-lake historical

279 water column TP (Fig. 2b). Whole-lake DI-TP trends suggest TP concentration was about $10 \mu \mathrm{g}$

$280 \mathrm{P} / \mathrm{L}$, which steadily increased to a peak of $\sim 18 \mu \mathrm{g}$ P/L in the 1970s. The DI-TP estimates appear

281 to be low compared to available monitoring data from the late 1960s, which indicate south basin

282 TP concentrations of 30-100 $\mu \mathrm{g}$ P/L (Reavie et al. 2017). After the 1970s, DI-TP values

283 remained between 15 and $17 \mu \mathrm{g}$ P/L until the most recent period (2005-2011) when whole-lake

284 DI-TP increased to over $24 \mu \mathrm{g}$ P/L. Comparison of DI-TP with monitored TP values from within

285 the cored basins suggest that average TP from 2005-2011 was $38 \mu \mathrm{g} \mathrm{P} / \mathrm{L}$ and $31 \mu \mathrm{g} / \mathrm{L}$ in 1999

286 based on roughly monthly late spring-summer sampling during focused monitoring efforts by

287 US and Canadian agencies. It is also apparent from the monitoring data that in the southern

288 basins there were distinctly higher TP readings in the late summer months $(>40 \mu \mathrm{g} \mathrm{P} / \mathrm{L})$

289 compared to spring (20-32 $\mu \mathrm{g} \mathrm{P} / \mathrm{L}$ ) values (Lake of the Woods Water Sustainability Foundation

290 2011, Reavie et al. 2017). Whole lake DI-TP (or for Model 2, calculated P concentration) was

291 multiplied by discharge at Big Narrows, which was estimated from 1900-2011 based on scaling

292 daily step outflows taken at both Kenora and Big Narrows from 2000-2010 (Fig. 5a; Zhang et al.

293 2013). 


\section{Modeling historical P dynamics}

295 Two, whole basin, modeling approaches were used to explore historical P loading scenarios to

296 LoW and in-lake nutrient dynamics.

\section{Model 1) Simple whole-lake mass balance}

298 We first applied a commonly used one-box whole-lake mass flux model to estimate historical P

299 loading in LoW (Rippey and Anderson 1996, Engstrom et al. 2009, Triplett et al. 2009,

300 Engstrom and Rose 2013):

$301 \quad \mathrm{I}=\mathrm{B}+\mathrm{O}$

302 where all external inputs (I) of P to a are either permanently buried in sediments (B), or removed 303 from the lake via outflow $(\mathrm{O})$. The sum of burial and outflow at any time is a first order estimate

304 of historical P loading to the lake. Modelled outflow $(\mathrm{O})$ is estimated using the whole-lake

305 historical diatom-inferred concentrations of TP (DI-TP; Fig. 2b) multiplied by the outflow at Big

306 Narrows (Fig. 5). Whole-lake burial (B) of P was calculated from focus-corrected flux rates of

307 total sediment $\mathrm{P}$ for each sub-basin as above (Fig. 4a). Burial of $\mathrm{P}$ is assumed to be permanent

308 with only minor internal loading and no mobility within sediments, i.e., observed sediment flux

309 reflects actual burial rate at each dated interval.

310 Model $1 \mathrm{P}$ loading estimates for LoW are estimated to be approximately $559 \mathrm{t} \mathrm{P} / \mathrm{yr}$ before

311 settlement (Table 2). Modern whole-lake load estimates (based on monitoring) are only slightly

312 higher and range from $582 \mathrm{t} \mathrm{P/yr} \mathrm{(2005-2014;} \mathrm{RESPEC,} \mathrm{unpublished)} \mathrm{to} 687 \mathrm{t} \mathrm{P/yr} \mathrm{(2005-2011;}$

313 Hargan et al. 2011). After settlement, model results suggest P loadings increase continuously to

314 modern rates of $1326 \mathrm{t} \mathrm{P} / \mathrm{yr}$ (Table 2). Based on monitored loading estimates (see Hargan et al.

315 2011, Anderson et al. 2013, Zhang et al. 2013), this model clearly overestimates modern

316 loadings to the lake. Importantly we also do not see any modeled decrease in loadings to the lake 
317 since the 1980s that would reflect well-documented decreases in P inputs from the Rainy River

318 (Hargan et al. 2011). A large over-estimate of modern P loads to the lake and no indication of

319 decreased loading after 1980 (Fig. 4a) reflect shortcomings of this model and limit its

320 applicability to sediment records deposited during steady state conditions during presettlement

321 times. The assumption that LoW rapidly and permanently removes external $\mathrm{P}$ from the lake via

322 burial is likely violated due to the within-core $\mathrm{P}$ mobility, high rates of resuspension, and slow

323 sedimentation rates.

\section{Model 2) Dynamic 3-box model with annual time step, 1860-2011}

325 To better estimate temporal changes in TP influx and in-lake fluxes, a three-box dynamic model

326 was constructed and run from 1860 to present (Fig. 6). In this case, modeled pools (inventories)

327 of $\mathrm{P}$ include buried sediment $\mathrm{P}$ (Cumulative buried $\mathrm{P}$, Fig. 4b), an active sediment pool of $\mathrm{P}$

328 (Cumulative $\mathrm{P}$ in active layer, Fig. 4b) available for exchange with the water column or burial,

329 and $\mathrm{P}$ in the water column (Lake P) from external and internal loading that are estimated using:

330 Cumulative $\mathrm{P}$ in active layer $=$ Ext Load $\mathrm{x} \%$ to Sed - Burial - InLoad

331 Cumulative buried $\mathrm{P}=($ Cum. $\mathrm{P}$ in active layer $/ \mathrm{MS}) \times$ Sed Rate

$$
\text { Lake P }=\text { Ext Load } x(1-\% \text { to Sed })+\text { InLoad }- \text { Out }
$$

333 Input data for Model 2 are the external P loads (Ext Load) from the Rainy River, which were

334 estimated annually for 1950s-2011 (Table 3), and other sources of P (other tributaries, shoreline 335 erosion, atmospheric deposition), which were held constant from 1850-2011 at 232 t P/yr (Table 336 3). Initial external load conditions (1850-1900) were set at 300 t P/yr from the Rainy River plus $337232 \mathrm{t} \mathrm{P} / \mathrm{yr}$ from other sources (total external load $532 \mathrm{t} \mathrm{P} / \mathrm{yr}$ ), similar to Model 1 presettlement 338 loading estimates (Table 3). From 1900 to 1950, P loads were increased incrementally to 1950s 339 monitoring estimates (Table 3). The model also incorporated a 10-year lag in burial; P that 
340 reached the sediments could not be permanently buried for 10 years, but remained available for

341 exchange with the water column as supported by the depth of mixing of ${ }^{7} \mathrm{Be}$ and data from other

342 large lakes (Nürnberg and LaZerte 2016).

343 Model variables that were manipulated included the percent of external load that goes

344 directly to sediment ( $\%$ to Sed), which ranged from range $0-50 \%$, based on our knowledge that

345 much of the P load from the Rainy River is in dissolved forms and readily available for in-lake

346 production. The mass of sediment in the active layer (MS), or the mass of sediment in the top 0-

$34710 \mathrm{~cm}$ depth increment; range 8.03 to $19.23 \mathrm{~kg} / \mathrm{m}^{2}$. MS represents the amount of sediment in the

348 layer that can exchange $\mathrm{P}$ with the lake before becoming buried. The mass of sediment and $\mathrm{P}$ in

349 this active layer determines the concentration of $\mathrm{P}$ at the time of permanent burial. The internal

350 loading rate (InLoad) was also manipulated and represents a net annual flux calculated as the \%

351 of $\mathrm{P}$ in the active layer that enters the lake through resuspension and/or redox cycling and

352 diffusion; range $0-2.5 \%$.

353 Model variables were manipulated through trial and error to best meet model target

354 criteria (Table 3). First, the model was evaluated against known or modeled in-lake

355 concentration of TP with targets set at $10 \mu \mathrm{g}$ P/L presettlement based on whole basin DI-TP

356 (Reavie et al.2017), 1960s TP monitored at approximately $70 \mu \mathrm{g} \mathrm{P} / \mathrm{L}$, and 2005-2011 TP values

357 using whole basin DI-TP of $25 \mu \mathrm{g}$ P/L (Reavie et al. 2017). The second model target was the

358 whole-basin inventory of P measured in sediments of southern LoW deposited in sediments from

359 1860-2011 (106,620 t P) and 1940-2011 (67,746 t P).

360 Target criteria were best satisfied when: a) $\%$ to Sed was set at $75 \%$, a reasonable number

361 given that at least a quarter of TP entering LoW from the Rainy River is dissolved P, b) the

362 InLoad was set at $2.5 \%$ of the Active Pool of P, and c) the active layer was defined as the top 0- 
$3635 \mathrm{~cm}$ of the core with a corresponding sediment mass (MS) of $8.03 \mathrm{~kg} / \mathrm{m}^{2}$. Model 2 results are

364 presented from 1860 to 2011 (the model was run from 1850-1860 to reach initial steady state

365 conditions, and extended to 2050 using current loading rates) and are best interpreted by

366 examining model estimates of water column TP and the size of the active pool of P (Fig. 7).

367 Dynamic modeling of LoW P fluxes appeared to overestimate background TP levels ( 20

$368 \mu \mathrm{g} \mathrm{P} / \mathrm{L}$ ) known from fossil diatom inferences but documented a rapid increase to a maximum of

$369 \sim 75 \mu \mathrm{g} \mathrm{P} / \mathrm{L}$ in the $1950 \mathrm{~s}$, before decreasing to modern levels of $\sim 25 \mu \mathrm{g} \mathrm{P} / \mathrm{L}$. The active pool of P

370 also increased rapidly after 1900 to maximum levels in the 1960s before declining to modern

371 levels by the 2010s. Preliminary analyses suggested that model output was sensitive to estimates

372 of external $\mathrm{P}$ influx. For example, if external loads are reduced to 232 tons $\mathrm{P} / \mathrm{yr}$ (value of other

373 sources of P; Table 3) from 1850-1900 model output more closely matches our presettlement

374 DI-TP estimate of $\sim 10 \mu \mathrm{g} \mathrm{P} / \mathrm{L}$ and the increase in water-column TP is delayed until about 1900,

375 concomitant with Euroamerican settlement, land use changes, and damming (Reavie and

376 Baratono 2007). Similarly, if the model is run through 2050 by holding P influx via the Rainy

377 River constant at current estimates of 350 tons $\mathrm{P} / \mathrm{yr}$, the lake reaches a steady state in the 2010 s

378 with water column TP of $25 \mu \mathrm{g} \mathrm{P} / \mathrm{L}$ and an active pool of 12000 tons P.

Model 2A overestimates initial water column TP in LoW at just over $20 \mu \mathrm{g} \mathrm{P} / \mathrm{L}$, shows a

380 rapid increase to peak levels of $77 \mu \mathrm{g} \mathrm{P} / \mathrm{L}$ in the $1950 \mathrm{~s}$, and then depicts slowly decreasing TP to

381 modern levels of $26 \mu \mathrm{g} \mathrm{P} / \mathrm{L}$. The active pool of $\mathrm{P}$ increases rapidly after 1900 to maximum levels

382 in the 1960s before declining to modern levels by the 2010s. Two modifications were made to

383 better understand model performance and future water quality trends. The model is highly

384 sensitive to external loads. Hence, if external loads are reduced to $232 \mathrm{t} \mathrm{P/yr} \mathrm{from} \mathrm{1850-1900}$

385 (equivalent to current sources of $\mathrm{P}$ other than the Rainy River), Model 2B output more closely 
matches our presettlement DI-TP estimate of $\sim 10 \mu \mathrm{g}$ P/L. Importantly, the increase in water

387 column TP is delayed until about 1900, which aligns with the timing of settlement, land use

388 changes, and damming. If the model is run through 2050 holding external loads from the Rainy

389 River at current estimates of $350 \mathrm{t} \mathrm{P} / \mathrm{yr}$, the lake reaches a steady state by 2020 with $\mathrm{TP}$ of $25 \mu \mathrm{g}$

$390 \mathrm{P} / \mathrm{L}$ and an active pool of $12,000 \mathrm{t} \mathrm{P}$.

391 Overall, Model 2 shows water column TP concentrations were $2 \mathrm{X}$ to $3 \mathrm{X}$ greater in the

392 1950s-1970s than today, and that decreased external loading after the 1970s resulted in

393 significant decreases of $\mathrm{P}$ concentration in the lake compared to the mid- $20^{\text {th }}$ century. The lake is

394 responsive to external loads because P burial and outflow are large net annual losses in LoW.

395 Similarly, the active pool of sediment $\mathrm{P}$ was largest in the 1960s and that legacy pool of $\mathrm{P}$ has

396 been rapidly depleted through burial or outflow to its current size of $10,000 \mathrm{tP}$. As such, the lake

397 will approach a new steady state with regard to water column TP and its active pool of P if

398 current loading trends continue.

\section{Discussion}

400 Paleolimnological analysis of sediment cores is widely used in lake management to determine

401 background or reference lake condition, periods and direction of lake change, an understanding

402 of potential drivers of change, and current ecosystem trajectories (Smol 2009). In LoW, the

403 paleolimnological approach was extended from a historical account of lake water quality and

404 ecological consequences (Reavie et al. 2017) to a whole-lake interpretation of the stratigraphy of

405 sediment $\mathrm{P}$ to more fully understand historical patterns of nutrient loading, quantify temporal

406 variability in lake-sediment $\mathrm{P}$ dynamics, and evaluate current trends in lake conditions using

407 traditional and dynamic modeling techniques. We organize our discussion of core records and 
408

409

410

411 Historical observations suggest that TP influx to LoW has declined from maxima during

412 the mid- $20^{\text {th }}$ century. For example, estimates of TP influx compiled by Beak Consultants

413 Ltd (1990) and Hargan et al. (2011) rigorously account for monitored TP loads from the

414 Rainy River as well as other tributary loads and sources during 1954-2011 (Table 3). These

415 data suggest that Rainy River P influx was greatest during the 1950 s $(\sim 1700 \mathrm{t}$ P/yr $)$ but

416 dropped by the 1970 s, with a steady decline to modern loadings that range from 237 to 559

$417 \mathrm{t} \mathrm{P} / \mathrm{yr}$ (Table 3; Zhang et al. 2013). At the same time, $\mathrm{P}$ from smaller tributaries,

418 atmospheric deposition, and shoreline erosion accounts for an additional $232 \mathrm{t} \mathrm{P} / \mathrm{yr}$ and

419 include inputs (Hargan et al. 2011, HEI 2013).

420

421 since ca. 1950. Instead geochemical analyses show the burden of P retained in the sediment

422 is mobile. Its gradual upcore diffusion increases the amount of $\mathrm{P}$ observed in the upper

423 sections of all cores and obscures the historical loading peak of the 1950s-1970s. This

424 phenomenon is not uncommon in lake sediment cores from eutrophic lakes, especially

425 those with relatively low sedimentation rates and with a higher propensity for recycling of

426 sedimentary P into the water column (Carey and Rydin 2011, Ginn et al. 2012). In contrast,

427 lakes with high sedimentation rates and rapid $\mathrm{P}$ burial can preserve known temporal

428 patterns of historical P influx (Engstrom et al. 2009, Triplett et al. 2009), and cores will

429 maintain that record based on repeat coring efforts separated by decades (Søndergaard et al.

430 2003, Blumentritt et al. 2013). 


\section{How have P loadings to LoW changed over the last 150 years?}

432 In LoW, a combination of paleolimnology, modeling, and monitoring was required to understand 433 that $\mathrm{P}$ loadings were estimated to have increased rapidly following settlement to peak levels in

434 the 1950s-1970s, after which loadings decreased rapidly following nutrient abatement

435 regulations. Past changes in $\mathrm{P}$ influx in the absence of monitoring data have been estimated using

436 a combination of whole-lake estimates of $\mathrm{P}$ burial and diatom-inferred estimates of water-column

437 TP. For example, this approach has proven successful in developing nutrient and sediment

438 reduction strategies in large transboundary lakes such as the Upper Mississippi River's Lake

439 Pepin and Lake St. Croix (Edlund et al. 2009, Engstrom et al. 2009; Triplett et al. 2009). In these

440 lakes, relatively high sedimentation rates provide rapid and efficient burial of $\mathrm{P}$ and a sediment

441 record that reflects trends in P loading. However, because LoW sediments do not preserve a

442 direct record of P loading, we cautiously applied a simple whole-lake mass balance model to

443 estimate presettlement loadings to LoW. If we assume that the presettlement sediment record in

444 LoW represents a long-term steady state, our Model 1 predicts presettlement $\mathrm{P}$ loading at $559 \mathrm{t}$

$445 \mathrm{P} / \mathrm{yr}$. Because of upcore mobility of $\mathrm{P}$ in the sediments, Model 1 is limited in its application to

446 presettlement (steady state) conditions. For other historical loading estimates we must rely on

447 monitoring data, which suggest peak loading from the Rainy River in the 1950s, slight declines

448 through the 1970 s, and a rapid decrease in loadings from the 1980 s to present. Other modern

449 sources of $\mathrm{P}$ are estimated at $232 \mathrm{t} \mathrm{P} / \mathrm{yr}$ and include inputs from minor tributaries, atmospheric

450 deposition, and shoreline erosion (Hargan et al. 2011, HEI 2013).

451 Can in-lake P dynamics be modeled to understand historical, legacy, and $452 \quad$ future nutrient dynamics? 
453 Model 2 explored the historical behavior of $\mathrm{P}$ in LoW that led to the modern distribution of

454 sediment $\mathrm{P}$. This model was necessary because the abundance and distribution of $\mathrm{P}$ fractions in

455 LoW sediment cores indicate there is a pool of readily exchangeable $\mathrm{P}$, and that pool of $\mathrm{P}$

456 increases at the top of the core. This pattern was clearly identified in all cores in this study and

457 by James (2017) from sites in Big Traverse and Muskeg bays. Because sediment P is potentially

458 mobile, the amount of $\mathrm{P}$ at a particular depth (and therefore time) is transient. If a core is

459 collected from LoW today, the downcore abundance of P is only a snapshot of current sediment

$460 \mathrm{P}$ distribution, and that distribution is a reflection of historical loading and in-lake processes that

461 control P loading (internal and external), deposition, mobility, and burial. Likewise, a core taken

462 in 1970 would have a different profile than today's core, and the interval dated from 1970 in

463 today's core will not look like it did in 1970 in geochemical terms.

464 Whereas many modeling efforts strive to disentangle $\mathrm{P}$ dynamics at the sediment water interface

465 and within the oxic/anoxic sediment boundary (e.g. Wang et al. 2003), our model uniquely

466 considered P dynamics at annual time steps on time frames greater than a century.

467 Model 2 results yield new insights on historical nutrient dynamics in LoW and

468 provide perspective on current and future water quality trends in the lake. First, water

469 column P was significantly higher in the past, particularly in the 1950s-1970s than it is

470 today. Second, the lake is very responsive to changes in external loads. Model results show

471 the lake quickly became more eutrophic as nutrient loading ramped up following

472 settlement, but also show that water column P levels quickly fell as external loads were

473 reduced after the 1970s. No long-term trend in outflow volume and P loss at Kenora was

474 noted that might account for this drop in water column P (Table 3). Third, the

475 responsiveness of the lake is a consequence of rapid and large burial and outflow fluxes 
476 that remove P from the lake. Last, with rapid reduction of external loads after the 1970s

477 and current external loads remaining relatively constant for the last decade, LoW has both

478 rapidly depleted any legacy pool of sediment $\mathrm{P}$ and has or will soon reach a new steady

479 state with respect to water column $\mathrm{P}$ and the size of its active pool of sediment $\mathrm{P}$.

480 Do trends in core biogeochemistry and biological indicators reflect

\section{$481 \quad$ historical nutrient dynamics?}

482 Biological remains preserved in the sediments of LoW record how ecological conditions

483 changed in the lake over the last 150 years in response to changing nutrient dynamics;

484 however, the indicators of historical algal productivity in LoW sediments offer somewhat

485 conflicting scenarios that need to be reconciled with our model reconstructions of historical

486 P loading and dynamics. Community changes in the diatoms are presented in detail

487 elsewhere (Reavie et al. 2017) and in conjunction with biogenic silica and fossil algal

488 pigments provide a record of historical diatom productivity. Historical changes in

489 cyanobacteria communities and productivity are similarly recorded by their fossilized

490 pigments.

491 Pigment profiles, particularly those of general algal indicators (e.g., lutein-

492 zeoxanthin) and diatom specific pigments (e.g., diatoxanthin) suggest two periods of high

493 productivity in the recent history of LoW. The first period occurred from the 1950s through

494 1970s, during the peak of nutrient influx to LoW, and was followed by a decline in

495 productivity in the 1980s followed by a second period of increased diatom productivity

496 since the 1990s. There are significant changes in diatom communities in the most recent

497 decades, particularly a greater abundance of species with higher TP optima including

498 Cyclostephanos dubius, several small Stephanodiscus species, and Aulacoseira granulata 
499 (Reavie et al. 2017). This most recent diatom community represents a species assemblage 500 not previously seen in the lake. Despite evidence from pigment proxies that suggest greater 501 diatom productivity in the 1950s-1970s there is no indication that the most recent high-P 502 indicator taxa were common in the 1950s-1970s. As such the DI-TP does not effectively 503 predict elevated P levels that were measured in the 1950s-1970s in LoW (Reavie et al. 504 2017, see Supplement C). Similarly, biogenic silica records, whether treated as a 505 concentration or flux, do not show increased diatom productivity during the 1950 s to 506 1970s, even though external P loading to the lake was higher and diatom pigment 507 indicators suggest higher productivity at that time (Reavie et al. 2017). Biogenic silica is 508 normally treated as a proxy for historical diatom productivity, but in LoW produces a 509 confounded record that is difficult to reconcile with sediment pigments and historical $\mathrm{P}$ 510 loading.

511 Fossil pigments also indicate two periods of elevated cyanobacterial production in 512 LoW. The first period is from the 1950s-1970s and is characterized by high concentrations 513 of cyanobacterial (e.g., echinone and canthaxanthin) and general algal indicators (e.g., 514 lutein-zeoxanthin) (Reavie et al. 2017). The same pigment groups show a second increase 515 since the 1990s in most cores. However, there is also an increase since the 1990s of an 516 additional pigment, myxoxanthophyll, an indicator of filamentous and colonial 517 cyanobacteria including several of the potentially toxic forms (e.g., Microcystis), further 518 suggesting that the biological communities present in the most recent decades are unique in 519 the recent history of LoW.

520 Recent biological changes in LoW seem paradoxical in relation to the simple 521 reduction of external $\mathrm{P}$ loads and depletion of the active pool of $\mathrm{P}$ as indicated by $\mathrm{P}$ 
522 monitoring and our modeling exercise. This incongruity suggests other factors must be

523 driving changes in the algal communities. One potential driver is a shift in nutrient

524 limitation. The few historical monitoring data on open-water nutrient stoichiometry suggest

525 that the lake was P-limited in the 1960s and that reduction of point-source inputs has

526 reduced $\mathrm{N}$ in a disproportionate ratio (relative to the Redfield ratio) to $\mathrm{P}$ leading to N-

527 limitation (Pla et al. 2005, Reavie et al. 2017), an environmental factor linked to enhanced

528 cyanobacterial production (Ferber et al. 2004, Orihel et al. 2012). Second, nutrient

529 abatement efforts targeted point source loads (principally the pulp/paper industry and

530 wastewater treatment plants), which has changed the seasonality of external loading to the

531 lake from the Rainy River from more constant loading to maximum loading occurring

532 April-June (J. Anderson, pers. comm.), likely affecting algal seasonality in the lake. Third,

533 climate warming may have exacerbated gains in water quality made through nutrient

534 abatement. Climate trends show minimal change in ice free season in the southern basin,

535 but warmer winters, and slightly warmer and calmer summers (Reavie et al. 2017). These

536 are factors that affect lake thermal conditions, internal loading, and algal seasonality and

537 productivity.

\section{$538 \quad$ Model Limitations}

539 With any modeling effort we must consider its limitations, future iterations, and potential

540 application to other lake management problems. The first key to this model's success is a

541 nearly 60-year record of P loading that exists for the the Rainy River, which contributes

$54270 \%$ of the P load to LoW (Beak Consultants Ltd 1990, Hargan et al. 2011). Although there

543 are few lakes that have loading data with this level of historical detail (e.g., Nürnberg and

544 LaZerte 2016), the model could be adapted to test alternative loading scenarios. We also 
545 recognize the limitations of historical monitoring data. For example, in our model we held 546 other external P sources constant from 1850-2011 at 232 t P/yr (Hargan et al. 2011, HEI

547 2013). However, other sources include other tributary inputs, atmospheric deposition,

548 shoreline erosion, and septic inputs, which were likely lower in presettlement times. Load

549 monitoring of the Rainy River deserves similar scrutiny, as monitoring data from the

5501950 s-1970s were spotty, and we may be underestimating loads that were missed during

551 periods of high runoff (J. Anderson, pers. comm.). Similarly we must reconcile spotty

552 monitoring data from the lake proper, which often recorded levels greater than $70 \mu \mathrm{g} \mathrm{P} / \mathrm{L}$ in

553 the 1960s, against low DI-TP estimates, which may be more indicative of spring TP values,

554 during this period of peak loading (see also below). Other model components that could be

555 refined include our model variables related to internal loading. We fix our internal loading

556 at $2.5 \%$ of the active pool of $\mathrm{P}$ annually. However, if lake conditions were significantly

557 different during the period of highest P loading (e.g. summer or winter hypolimnetic

558 anoxia), internal loading may have historically had a greater role in nutrient dynamics. We

559 further assume that $\mathrm{P}$ first entering the sediments was not buried for 10 years, consistent

560 with results from Lake Winnipeg sediments (Matisoff et al. 2017). Despite such model

561 limitations and uncertainties, all combinations of variables show unequivocally that $\mathrm{P}$

562 concentrations in LoW were much higher in the past, and that the active pool of P declined

563 over the past several decades. Most critically, we cannot create a scenario in which legacy

$564 \mathrm{P}$ is a major driver of current conditions, providing a robust mechanistic argument against

565 this hypothesis.

\section{Management implications}


567 Downcore profiles and model results have several important management implications for

568 LoW and for other large shallow lake systems. First, we show that water-column

569 concentrations of $\mathrm{P}$ in southern LoW declined markedly since the 1970s through nutrient

570 abatement programs that reduced external P loading. Analysis with dynamic modeling

571 indicates that the active pool of $\mathrm{P}$ was rapidly depleted from its mid-20th century maximum

572 via burial and outflow, and the lake has recently or should soon reach a new steady state in

573 the absence of future stressors. The combined losses of P through outflow and burial are

574 substantial in LoW, making the lake responsive to future reductions in external P inputs, if

575 further loading reductions are possible. In contrast, lakes with long residence times and/or

576 slow sedimentation rates are hampered in their ability to remove $\mathrm{P}$ through outflow or

577 burial and will remain management challenges (Jeppesen et al. 2005, McCrackin et al.

578 2016).

579 Second, from a biological standpoint, we cannot say that the frequency and extent

580 of cyanobacterial blooms is greater today than in the past in LoW. Fossil pigment records

581 indicate that cyanobacterial blooms were also a large part of the ecology of LoW in the

582 1950s-1970s (Reavie et al. 2017). However, we know from fossil pigments (increase in

583 myxoxanthophyll) that the modern cyanobacterial community is different than what was

584 present earlier. The diatoms similarly suggest a historically unique modern scenario as

585 communities have shifted toward more eutrophic indicators in recent decades, similar to the

586 northern LoW “disturbed” sites studied by Rühland et al. (2010), and that diatom

587 productivity based on biogenic silica is currently at its highest recorded levels. There is no

588 evidence of selective downcore dissolution in the cores to suggest the upcore record is

589 biased (Reavie et al. 2017). 
It is the cause of recent algal community shifts and potential limnological shifts that

591 must concern lake managers. Could the algal communities be responding to drivers other

592 than P in light of the well documented decreases in P loading and depletion of the legacy

593 sediment P pool? Three potential drivers should be explored. Nutrient loading from the

594 Rainy River has shifted from continuous loading to pulsed (seasonal) loading following

595 nutrient abatement efforts that targeted sanitary and industry sources (J. Anderson, pers.

596 comm.). Modern loadings are now highest in April-June and may have changed algal

597 ecology where large and heavily silicified diatoms are favored in spring whereas

598 cyanobacteria and smaller centric diatoms are favored later in the season. This response

599 may be exacerbated by the second driver, a shift from P-limitation in the main body of

600 LoW in the 1960s to N-limitation or co-limitation since the 1990s (Reavie et al. 2017)

601 based on DIN:TP (Bërgstrom 2010). Although not a perfect predictor of cyanobacterial

602 dominance (Downing et al. 2001), N-limitation has been linked to bloom formation (Ferber

603 et al. 2004, Orihel et al. 2012).

604 Last, climate changes are already evident in LoW. In its northern basins, the ice-

605 free season has been extended by nearly four weeks since the 1960s (Rühland et al. 2010)

606 with winter and summer temperatures at Kenora (Ontario) $2.3^{\circ} \mathrm{C}$ and $1.2^{\circ} \mathrm{C}$ warmer since

607 1900, respectively. This has resulted in increases in algal production (Paterson et al. 2017)

608 and changes in diatom and chironomid assemblages (Rühland et al. 2008, 2010, Hyatt et al.

609 2011, Summers et al. 2012) that are consistent with changes in lake physical properties and

610 water column nutrient cycling (e.g., internal loading). In contrast, the southern basin shows

611 no discernable trend in ice-out date (MNDNR-SCO 2016). Nevertheless, climate drivers

612 will affect the physical, chemical, and biological limnology of the lake through longer 
613 growing seasons, seasonality of external loads, and increased potential for short-term

614 stratification. Understanding the links between these drivers, water quality, and algal

615 ecology should be the focus of research, monitoring, and modeling on Lake of the Woods.

\section{Acknowledgments}

617 We thank the Minnesota Pollution Control Agency (MPCA; Contract 41642) and the Lake of the

618 Woods Sustainability Foundation for providing funding for this project. Fieldwork was

619 supported by the MPCA, the Sportsman's Lodge, and Captain Randy Beebe from WolfsHead

620 Research Logistics aboard the R/V Arctic Fox. Devin Hougardy and Aaron DeRusha provided

621 field assistance. Kathryn Hargan (PEARL, Queens University) and Geoff Kramer (RESPEC) and

622 Jesse Anderson (MPCA) provided historical loading data, Brittany Store (MPCA) provided GIS

623 data, Matt DeWolfe (lwcb.ca) provided outflow data for the Winnipeg River. Norman Andresen

624 (Andresen LLC, Ypsilanti, Michigan) analyzed diatoms in cores. Erin Mittag, Michele

625 Natarajan, Erin Mortenson, and Alaina Fedie of the St. Croix Watershed Research Station

626 coordinated lab analyses. Reviewers provided valuable comments that significantly improved the

627 project.

628 References

629 Anderson J, Baratono N, Heiskary S, Wilson B. 2013. Updated Total Phosphorus Budget for 630 Lake of the Woods, Proceedings of the 2013 International Lake of the Woods Water 631 Quality Forum, International Falls, MN, U.S.A.

632 Anderson JP, Paterson AM, Reavie ED, Edlund MB, Rühland KM. 2017. An introduction to

633 Lake of the Woods - from science to governance on an international waterbody. Lake 634 Reserv Manage. (this issue) 
Anderson NJ, Rippey B, Gibson CE. 1993. A comparison of sedimentary and diatom-inferred phosphorus profiles: implications for defining pre-disturbance nutrient conditions. Hydrobiologia 253:357-366.

Appleby PG. 2001. Chronostratigraphic techniques in recent sediments. In: Last WM, Smol JP, editors. Tracking Environmental Change Using Lake Sediments. Volume 1: Basin analysis, Coring, and Chronological Techniques. Dordrecht: Kluwer Academic Publishers. p. 171-203.

Appleby PG, Oldfield F. 1978. The calculation of lead-210 dates assuming a constant rate of supply of the unsupported lead-210 to the sediment. Catena 5:1-8.

Beak Consultants Ltd. 1990. The Rainy River Water Quality Study. Final Report. Prepared for Boise Cascade Canada Ltd and Boise Cascade Corporation, International Falls, MN. Beak Consultants Limited, 595 Woowich Street, Guelph, Ontario.

Bergström AK. 2010. The use of TN: TP and DIN: TP ratios as indicators for phytoplankton nutrient limitation in oligotrophic lakes affected by N deposition. Aquat Sci. 72(3):277281.

Binding CE, Greenberg TA, Jerome JH, Bukata RP, Letourneau G. 2011. An assessment of MERIS algal products during an intense bloom in Lake of the Woods. J Plankton Res. $33: 1847-1852$.

Binford MW. 1990. Calculation and uncertainty analysis of 210-Pb dates for PIRLA project lake sediment cores. J Paleolimnol. 3:253-267.

Blumentritt DJ, Engstrom DR, Balogh SJ. 2013. A novel repeat-coring approach to reconstruct recent sediment, phosphorus, and mercury loading from the upper Mississippi River to Lake Pepin, USA. J Paleolimnol. 50:293-304. 
658 Boström B, Jansson M, Forsberg C. 1982. Phosphorus release from lake sediments. Arch Hydrobiol - Beih Ergeb Limnol. 18:5-59.

660 Brenner M, Hodell DA, Leyden BW, Curtis JH, Kenney WF, Gu B, Newman JM. 2006. Mechanisms for organic matter and phosphorus burial in sedimentsof a shallow,

663 Bunting L, Leavitt PR, Simpson GL, Wissel B, Laird KR, Cumming BF, St Amand A, Engstrom DR. 2016. Increased variability and sudden ecosystem state change in Lake Winnipeg,

Carey CC, Rydin E. 2011. Lake trophic status can be determined by the depth distribution of Canada, caused by 20th century agriculture. Limnol Oceanogr. 61:2090-2107. sediment phosphorus. Limnol Oceanogr. 56:2051-2063

Chen H, Burke JM, Mosindy T, Fedorak PM, Prepas EE 2009. Cyanobacteria and microcystinLR in a complex lake system representing a range in trophic status: Lake of the Woods, Ontario, Canada, J Plankton Res. 31:993-1008.

Chen H, Burke JM, Dinsmore WP, Prepas EE, Fedorak PM. 2007. First assessment of cyanobacterial blooms and microcystin-LR in the Canadian portion of Lake of the Woods. Lake Reserv Manage. 23:169-178.

Clark BJ, SellersTJ, Baratono NG, DeSellas AM, Maki R, McDaniel T, Mosindy T, Pascoe T, Paterson AM, Rühland K, et al. 2014. Rainy-Lake of the Woods State of the basin report, $2^{\text {nd }}$ edition. Kenora (on): Lake of the Woods Water Sustainability Foundation. 225 pp.

DeSellas AM, Paterson AM, Clark BJ, Baratono NG. 2009. State of the basin report for the Lake of the Woods and Rainy River basin. Kenora $(\mathrm{ON})$ : Lake of the Woods Water Sustainability Foundation. 
Downing JA, Watson SB, McCauley E. 2001. Predicting cyanobacteria dominance in lakes. Can J Fish Aquat Sci. 58:1905-1908.

682 Edlund MB, Engstrom DR, Triplett L, Lafrancois BM, Leavitt PR. 2009. Twentieth-century eutrophication of the St. Croix River (Minnesota-Wisconsin, USA) reconstructed from the sediments of its natural impoundment. J Paleolimnol. 41:641-657.

Engstrom DR. 2005. Long-term changes in iron and phosphorus sedimentation in Vadnais Lake, Minnesota, resulting from ferric chloride addition and hypolimnetic aeration. Lake Reserv Manage. 21:95-105.

Engstrom DR, Rose NL. 2013. A whole-basin, mass-balance approach to paleolimnology. J Paleolimnol. 49:333-347.

Engstrom DR, Wright HE Jr. 1984. Chemical stratigraphy of lake sediments as a record of environmental change. In: Haworth EY, editor. Lake sediments and environmental

Engstrom DR, Almendinger JE, Wolin JA. 2009. Historical changes in sediment and phosphorus loading to the upper Mississippi River: mass-balance reconstructions from the sediments

Ferber LR, Levine SN, Lini A, Livingston GP. 2004. Do cyanobacteria dominate in eutrophic lakes because they fix atmospheric nitrogen? Freshwater Biol. 49:690-708.

Ginn BK, Rühland KM, Young JD, Hawryshyn J, Quinlan R, Dillon PJ, Smol JP. 2012. The perils of using sedimentary phosphorus concentrations for inferring long-term changes in lake nutrient levels: Comments on Hiriart-Baer et al., 2011. J Great Lakes Res. 38:825829. 
702 Hargan KE, Paterson AM, Dillon PJ. 2011. A total phosphorus budget for the Lake of the Woods and Rainy River catchment. J Great Lakes Res. 37:753-763.

704 Havens KE, Fukushima T, Xie P, Iwakuma T, James RT, Takamura N, Hanazato T, Yamamoto T. 2001. Nutrient dynamics and the eutrophication of shallow lakes Kasumigaura (Japan), Donghu (PR China), and Okeechobee (USA). Environ Pollut. 111:263-272.

[HEI] Houston Engineering Inc. 2013. Lake of the Woods Sediment \& Nutrient Budget Investigation: Focusing on Watershed and Southern Shoreline Loads. Final report to Lake of the Woods SWCD (USEPA Contract \#X7-00E00918), 78 pp.

710 Hobbs WO, Engstrom DR, Schottler SP, Zimmer KD, Cotner JB. 2013. Estimating modern

711 carbon burial rates in lakes using a single sediment sample. Limnol Oceanogr-Meth.

$712 \quad 11: 316-326$.

713 Hyatt CV, Paterson AM, Rühland KM, Smol JP. 2011. Examining 20th century water quality

714 and ecological changes in the Lake of the Woods, Ontario, Canada: A paleolimnological

715 investigation. J Great Lakes Res. 37:456-469.

716 James WF. 2017. Internal phosphorus loading contributions from deposited and resuspended

717 sediment to the Lake of the Woods. Lake Reserv Manage.

$718 \quad$ doi.org/10.1080/10402381.2017.1312647

719 James WF, Barko JW. 1993. Analysis of summer phosphorus fluxes within the pelagic zone of

720 Eau Galle Reservoir, Wisconsin. Lake Reserv Manage. 8:61-66.

721 James WF, Sorge PW, Garrison PJ. 2015. Managing internal phosphorus loading and vertical

722 entrainment in a weakly stratified eutrophic lake. Lake Reserv Manage. 31:292-305. 
723 Jeppesen E, Søndergaard M, Jensen JP, Havens KE, Anneville O, Carvalho L, et al. 2005. Lake responses to reduced nutrient loading - an analysis of contemporary long-term data from 35 case studies. Freshwater Biol. 50:1747-1771.

726 Kopáček J, Marešová M, Hejzlar J, Norton SA. 2007. Natural inactivation of phosphorus by 727 aluminum in preindustrial lake sediments. Limnol Oceanogr. 2007 May 1;52(3):1147$728 \quad 1155$

729 Lake of the Woods Sustainability Foundation. 2011. Phosphorus Budget Studies in the Lake of the Woods Watershed. Kenora (ON): Lake of the Woods Sustainability Foundation. 27 pp.

Lamborg CH, Engstrom DR, Fitzgerald WF, Balcom PH. 2013. Apportioning global and nonglobal components of mercury deposition through $210 \mathrm{~Pb}$ indexing. Sci Total Environ. 448:132-140.

Matisoff G, Watson SB, Guo J, Duewiger A, Steely R. 2017. Sediment and nutrient distribution and resuspension in Lake Winnipeg. Sci Total Environ. 575:173-186.

McCrackin ML, Jones HP, Jones PC, Moreno-Mateos D. 2016. Recovery of lakes and coastal marine ecosystems from eutrophication: A global meta-analysis. Limnol Oceanogr. doi:

742 Norton SA, Perry RH, Saros JE, Jacobson GL, Fernandez IJ, Kopáček J, Wilson TA, 743 SanClements MD. 2011. The controls on phosphorus availability in a Boreal lake ecosystem since deglaciation. J Paleolimnol. 46:107-122. 
745 Nürnberg GK, LaZerte BD. 2016. More than 20 years of estimated internal phosphorus loading 746 in polymictic, eutrophic Lake Winnipeg, Manitoba. J Great Lakes Res. 42:18-27.

747 Orihel DM, Bird DF, Brylinsky M, Chen H, Donald DB, Huang DY, Giani A, Kinniburgh D, 748 Kling H, Kotak BG, et al. 2012. High microcystin concentrations occur only at low 749 nitrogen-to-phosphorus ratios in nutrient-rich Canadian lakes. Can J Fish Aquat Sci. $750 \quad 69: 1457-1462$.

751 Paerl HW, Huisman J. 2008. Blooms like it hot. Science 320:57-58.

752 Paerl HW, Hall NS, Calandrino ES. 2011. Controlling harmful cyanobacterial blooms in a world 753 experiencing anthropogenic and climatic-induced change. Sci Total Enviro. $754 \quad 409(10): 1739-1745$.

755 Paterson AM, Rühland KM, Anstey CV, Smol JP. 2017. Climate as a driver of increasing algal 756 production in Lake of the Woods, Ontario, Canada. Lake Reserv Manage. (this issue)

757 Pla S, Paterson AM, Smol JP, Clark BJ, Ingram R. 2005. Spatial variability in water quality and 758 759

Reavie ED, Edlund MB, Andresen NA, Engstrom DR, Leavitt PR, Schottler S, Cai M. 2017. Paleolimnology of the Lake of the Woods southern basin: Continued water quality 766 degradation despite lower nutrient influx. Lake Reserv Manage. doi.org/10.1080/10402381.2017.1312648 
768 Renberg I, Hansson H. 2008. The HTH sediment corer. J Paleolimnol. 40:655-659.

769 Rippey B, Anderson NJ. 1996. Reconstruction of lake phosphorus loading and dynamics using 770 the sedimentary record. Environ Sci Technol. 30:1786-1788.

771 Rühland K, Paterson AM, Smol JP. 2008. Hemispheric-scale patterns of climate-related shifts in 772 planktonic diatoms from North American and European lakes. Global Change Biol. $773 \quad 14: 2740-2754$.

774 Rühland K, Paterson AM, Hargan KE, Jenkin A, Michelutti N, Clark BJ, Smol JP. 2010.

775 Reorganization of algal communities in Lake of the Woods (Ontario, Canada) in response 776 to turn of the century damming and recent warming. Limnol Oceanogr. 55:2433-2451.

777 Schindler DW. 2012. The dilemma of controlling cultural eutrophication of lakes. P Roy Soc $778 \quad$ Lond B: Bio. rspb20121032.

779 Schindler DW, Carpenter, SR, Chapra, SC, Hecky RE, Orihel DM. 2016. Reducing phosphorus to curb lake eutrophication is a success. Environ Sci Technol. 50:8923-8929.

781 Smol JP. 2009. Pollution of lakes and rivers: a paleoenvironmental perspective, $2^{\text {nd }}$ Ed. Oxford 782 (UK): Blackwell Publishing.

783 Søndergaard M, Jensen JP, Jeppesen E. 2003. Role of sediment and internal loading of 784 phosphorus in shallow lakes. Hydrobiologia 506(1-3):135-145.

785 Summers JC, Rühland KM, Kurek J, Quinlan R, Paterson AM, Smol JP. 2012. Multiple stressor 786 effects on water quality in Poplar Bay, Lake of the Woods, Canada: a midge-based 787 assessment of hypolimnetic oxygen conditions over the last two centuries. J Limnol. $788 \quad 71: 34-44$. DOI: $\underline{10.4081 / j \text { limnol.2012.e3 }}$ 
Tomkins JD., Antoniades D, Lamoureux SF, Vincent WF. 2008. A simple and effective method for preserving the sediment-water interface of sediment cores during transport. $\mathrm{J}$ Paleolimnol. 40:577-582.

792

Triplett LD, Engstrom DR, Edlund MB. 2009. A whole-basin stratigraphic record of sediment and phosphorus loading to the St. Croix River, USA. J Paleolimnol. 41:659-677. DOI:10.1007/s10933-008-9290-7

[USEPA] US Environmental Protection Agency. 2016. National Lakes Assessment 2012: A Collaborative Survey of Lakes in the United States. Washington (DC): EPA 841-R-16113, https://nationallakesassessment.epa.gov/

Wang H, Appan A, Gulliver JS. 2003. Modeling of phosphorus dynamics in aquatic sediments: I—model development. Water Res. 37(16):3928-3938.

Wilson TA, Amirbahman A, Norton SA, Voytek MA. 2010. A record of phosphorus dynamics in oligotrophic lake sediment. J Paleolimnol. 44:279-294.

Wright HE Jr. 1991. Coring tips. J Paleolimnol. 6:37-49.

Xie L, Xie P. 2002. Long-term (1956-1999) dynamics of phosphorus in a shallow, subtropical Chinese lake with the possible effects of cyanobacterial blooms. Water Res. 36:343-349. Zhang W, Watson SB, Yerubandi RR, Kling HJ. 2013. A linked hydrodynamic, water quality and algal biomass model for a large, multi-basin lake: A working management tool. Ecol Model. 269:37-50. 
Tables

811

812

813

814

815

816

817

818

819

820

821

822

823

824

Table 2. Model 1 output where I = B + O, P Inputs (I), P Burial (B), and P Outflow (O) are in tonnes P/yr. P Outflow is estimated from diatom-inferred TP (Reavie et al. 2017) multiplied by outflow volume (see Table 3 ).

\begin{tabular}{lccc}
\hline $\begin{array}{c}\text { Time Interval } \\
\text { (years) }\end{array}$ & $\begin{array}{c}\text { P Input } \\
\text { (t P/yr) }\end{array}$ & $\begin{array}{c}\text { P Outflow } \\
\text { (t P/yr) }\end{array}$ & $\begin{array}{c}\text { P Burial } \\
\text { (t P/yr) }\end{array}$ \\
\hline $2005-2011$ & 1326 & 361.0 & 965 \\
$2000-2004$ & 1080 & 270.4 & 809 \\
$1995-1999$ & 1000 & 278.5 & 721 \\
$1990-1994$ & 908 & 243.7 & 664 \\
$1980-1989$ & 806 & 219.7 & 586 \\
$1970-1979$ & 753 & 286.1 & 467 \\
$1960-1969$ & 701 & 279.6 & 422 \\
$1950-1959$ & 935 & 221.2 & 714 \\
$1940-1949$ & 859 & 215.1 & 644 \\
$1920-1939$ & 712 & 147.2 & 564 \\
$1900-1919$ & 676 & 153.0 & 523 \\
pre-1900 & 559 & 128.2 & 431 \\
\hline
\end{tabular}

Table 1. Lake of the Woods core names, dates, coring locations, depth at core site, and core recovery. Focusing factors are estimated by the flux of unsupported ${ }^{210} \mathrm{~Pb}$ to the core site relative to known atmospheric depositional rates in the region $\left(\sim 0.45 \mathrm{pCi} / \mathrm{cm}^{2} \mathrm{yr}\right)$.

\begin{tabular}{lcccccccc}
\hline Core Name & $\begin{array}{c}\text { Date } \\
\text { yyymmdd }\end{array}$ & $\begin{array}{c}\text { Lat }(\mathrm{N}) \\
{ }^{\circ} \mathrm{N}\end{array}$ & $\begin{array}{c}\text { Long }(\mathrm{W}) \\
{ }^{\circ} \mathrm{W}\end{array}$ & $\begin{array}{c}\text { State/Prov } \\
\text { type }\end{array}$ & $\begin{array}{c}\text { Depth } \\
(\mathrm{m})\end{array}$ & $\begin{array}{c}\text { Recovery } \\
(\mathrm{m})\end{array}$ & $\begin{array}{c}\text { Focus } \\
\text { factor }\end{array}$ \\
\hline LoW_BigNarrows & 20120228 & $49.39472^{\circ}$ & $94.79395^{\circ}$ & Ontario & Piston & 8.53 & 0.98 & 1.68 \\
LoW_LittleTrav & 20120228 & $49.24643^{\circ}$ & $94.67145^{\circ}$ & Ontario & Piston & 9.18 & 0.98 & 1.37 \\
LoW_Sabaskong & 20120229 & $49.10064^{\circ}$ & $94.42108^{\circ}$ & Ontario & Piston & 6.85 & 0.98 & 1.87 \\
LoW_BigTrav3 & 20120229 & $49.01931^{\circ}$ & $94.75391^{\circ}$ & Minnesota & Piston & 10.2 & 0.9 & 1.21 \\
LoW_BigTrav4 & 20120301 & $49.08941^{\circ}$ & $94.99497^{\circ}$ & Minnesota & Piston & 10.13 & 0.96 & 1.44 \\
LoW_Muskeg & 20120301 & $48.97849^{\circ}$ & $95.17970^{\circ}$ & Minnesota & Piston & 8.08 & 0.95 & 1.59 \\
LoW_BB2H & 20120818 & $49.10960^{\circ}$ & $95.22796^{\circ}$ & Manitoba & HTH & 5.52 & 0.095 & 0.41 \\
\hline
\end{tabular}


826 Table 3. Model 2 input data, parameters, and data sources.

\begin{tabular}{|c|c|c|c|}
\hline Parameter & Value & Units & Source \\
\hline Surface Area of Lake & $2.83 \times 10^{9}$ & $\mathrm{~m}^{2}$ & GIS \\
\hline Volume of Lake & $18.48 \times 10^{9}$ & $\mathrm{~m}^{3}$ & 1 \\
\hline \multicolumn{4}{|l|}{ Outflow at Big Narrows } \\
\hline $1850-1930$ & $10.7 \times 10^{9}$ & $\mathrm{~m}^{3} / \mathrm{yr}$ & 1,4 \\
\hline 1940 & $13.7 \times 10^{9}$ & $\mathrm{~m}^{3} / \mathrm{yr}$ & 1,4 \\
\hline 1950 & $12.9 \times 10^{9}$ & $\mathrm{~m}^{3} / \mathrm{yr}$ & 1,4 \\
\hline 1960 & $15.8 \times 10^{9}$ & $\mathrm{~m}^{3} / \mathrm{yr}$ & 1,4 \\
\hline 1970 & $15.6 \times 10^{9}$ & $\mathrm{~m}^{3} / \mathrm{yr}$ & 1,4 \\
\hline 1980 & $12.8 \times 10^{9}$ & $\mathrm{~m}^{3} / \mathrm{yr}$ & 1,4 \\
\hline 1990 & $14.4 \times 10^{9}$ & $\mathrm{~m}^{3} / \mathrm{yr}$ & 1,4 \\
\hline $2000-2050$ & $14.9 \times 10^{9}$ & $\mathrm{~m}^{3} / \mathrm{yr}$ & 1,4 \\
\hline
\end{tabular}

Phosphorus Load from Rainy River

$\begin{array}{rccc}1850-1900 & 300 & \mathrm{t} / \mathrm{yr} & 5 \\ 1900 & 400 & \mathrm{t} / \mathrm{yr} & 5 \\ 1910 & 500 & \mathrm{t} / \mathrm{yr} & 5 \\ 1920 & 600 & \mathrm{t} / \mathrm{yr} & 5 \\ 1930 & 800 & \mathrm{t} / \mathrm{yr} & 5 \\ 1940 & 1000 & \mathrm{t} / \mathrm{yr} & 5 \\ 1950 & 1176 & \mathrm{t} / \mathrm{yr} & 3 \\ 1960 & 1319 & \mathrm{t} / \mathrm{yr} & 2,3 \\ 1970 & 830 & \mathrm{t} / \mathrm{rr} & 2,3 \\ 1980 & 546 & \mathrm{t} / \mathrm{yr} & 2,3 \\ 1990 & 519 & \mathrm{t} / \mathrm{yr} & 2,3 \\ 2000 & 377 & \mathrm{t} / \mathrm{yr} & 2,3 \\ 2000-2050 & 350 & \mathrm{t} / \mathrm{yr} & 2,3\end{array}$

Phosphorus load from other sources

1850-2050 $232 \quad \mathrm{t} / \mathrm{yr} \quad 2,6$

Whole basin sediment accumulation rate (areal)

$\begin{array}{llll}1850-1900 & 0.238 & \mathrm{~kg} / \mathrm{m}^{2} / \mathrm{yr} & 5 \\ 1900-1919 & 0.288 & \mathrm{~kg} / \mathrm{m}^{2} / \mathrm{yr} & 5 \\ 1920-1939 & 0.335 & \mathrm{~kg} / \mathrm{m}^{2} / \mathrm{yr} & 5 \\ 1940-1949 & 0.318 & \mathrm{~kg} / \mathrm{m}^{2} / \mathrm{yr} & 5 \\ 1950-1959 & 0.341 & \mathrm{~kg} / \mathrm{m}^{2} / \mathrm{yr} & 5 \\ 1960-1969 & 0.353 & \mathrm{~kg} / \mathrm{m}^{2} / \mathrm{yr} & 5 \\ 1970-1979 & 0.384 & \mathrm{~kg} / \mathrm{m}^{2} / \mathrm{yr} & 5 \\ 1980-1989 & 0.417 & \mathrm{~kg} / \mathrm{m}^{2} / \mathrm{yr} & 5 \\ 1990-1999 & 0.469 & \mathrm{~kg} / \mathrm{m}^{2} / \mathrm{yr} & 5 \\ 2000-2050 & 0.506 & \mathrm{~kg} / \mathrm{m}^{2} / \mathrm{yr} & 5\end{array}$

827 *Supporting data: 1) Zhang et al. 2013; 2) Hargan et al. 2011; 3) Beak Consultants Ltd 1990; 4) Matt DeWolfe 828 (Iwcb.ca); 5) this study; 6) HEI 2013 


\section{Figures}

Figure 1. Downcore profiles for seven Lake of the Woods cores for total ${ }^{210} \mathrm{~Pb}$ activity, datedepth relationship, and sedimentation rate plotted against core depth $(\mathrm{cm})$. Dashed line in ${ }^{210} \mathrm{~Pb}$ inventory represents level of supported ${ }^{210} \mathrm{~Pb}$.

Figure 2. Whole basin estimates of focus corrected sediment accumulation and diatom-inferred historical water column total P plotted against time period. Fig. 2a. Whole basin estimates of focus corrected sediment accumulation $\left(\mathrm{kg} / \mathrm{m}^{2} \mathrm{yr}\right)$. Fig. $2 \mathrm{~b}$. Whole basin estimates of water column diatom-inferred total P (DI-TP; $\mu \mathrm{g} / \mathrm{L})$.

Figure 3. Geochemistry of seven Lake of the Woods cores including concentration (mg P/g sediment) and flux (mg P/ $\mathrm{cm}^{2} \mathrm{yr}$ ) of total sediment phosphorus and phosphorus fractions including $\mathrm{HCl}-\mathrm{P}, \mathrm{NaOH}-\mathrm{P}$, Organic-P, and Exchangeable-P, and water column diatom-inferred total phosphorus (DI-TP; $\mu \mathrm{g} / \mathrm{L}$ ) estimates from Reavie et al. (2017) plotted against core date.

Figure 4. Whole basin estimates of historical accumulation of phosphorus $(\mathrm{P})$ and $\mathrm{P}$ fractions in Lake of the Woods sediments by time period. Fig. 4a. Accumulation of P differentiated into refractory components (HCl-P and Organic-P; green bars) and labile components ( $\mathrm{NaOH}-\mathrm{P}$ and Exchangeable-P; yellow bars); minimum burial estimates of refractory fractions were used in Model 2. Fig. 4b. Conceptual model of the Active and Buried inventory of P present in 2011 (see text for details).

Figure 5. Outflow and P loss at Big Narrows. Fig. 5a. Historical flows at Big Narrows for each time period, $\mathrm{km}^{3} \mathrm{yr}^{-1}$. Fig. 5b. Estimates of historical loss of phosphorus through outflow at Big Narrows by time period (lower panel). P loss represents the whole-lake historical diatominferred total phosphorus multiplied by historical flows at Big Narrows for each time period.

Figure 6. Model 2 is a three-box dynamic model run from 1850-2050. Three inventories of $\mathrm{P}$ are estimated including $\mathrm{P}$ in the lake (Lake P), Cumulative $\mathrm{P}$ in the Active Layer, and Cumulative $\mathrm{P}$ in the Buried Layer by adjusting the percent of external P load (EX) that goes to the sediment (\% to Sed), the internal load rate (InLoad), and the mass of sediment (MS) that is in the Active Layer.

Figure 7. Output of Model 2, 1860-2050. Model 2B (blue line) is based on lower external inputs in presettlement times compared to Model 2A (red line; see text). Fig. 7a. Modeled water column TP $(\mu \mathrm{g} / \mathrm{L})$ peaks in 1950-60s with rapid water quality improvement after 1960s (blue line). Model 2B delays the rise of TP until 1900 (red line) but has no effect post-1960s. Stable TP levels are reached by 2015-2020 if modern external loads remain constant. Fig. 7b. Modeled P in the active layer of Lake of the Woods sediments. The active pool of P was greatest in the 1960s regardless of presettlement external load scenarios, and legacy $\mathrm{P}$ has been rapidly reduced since the 1960s. Model output suggests the active pool of sediment P is reaching a stable condition. 